\title{
Demographic and statistical study of covid-19: Transmission and drug susceptibility pattern in India
}

\author{
Talluri Rameshwari K R, Anuradha K and Ajay Kumar Singh
}

\begin{abstract}
Corona virus is a novel virus, causes severe acute respiratory syndrome (SARS) and spreading worldwide from person to person via communicable disease. It was first identified in the Wuhan City, Hubei Province, China in December 2019 hence it got the name COVID-19. In India, COVID-19 cases are reported severe as compared with other countries and it is standing in second position in the world after United State of America. The pathogenesis of COVID-19 is more risk in elder age as compared to young ones due to immune response. The pathogenesis of COVID-19 is recorded in three steps 1) asymptomatic state, 2) upper airways and conducting airways response and 3) hypoxia. The drugs viz., hydroxychloroquine, paracetamol, and antibiotics are mostly used for the treatment of SARS but no single drug is effective for disease. Hence, treatment of this disease is required. In this review, the correlation of confirmed and death cases due to COVID-19 in India and China are analysed by statistical methods (one-way ANOVA and tTest). This study will give a clear picture of COVID-19 disease scenario and also helped in identifying and preventing the disease.
\end{abstract}

Index Terms - COVID-19 Cases, Pathogenesis, SPSS Statistics, Transmission, Descriptive Analysis, One WayANOVA, Drug susceptibility

\section{INTRODUCTION}

$\mathrm{D}$ ecember - 2019, the Coronavirus disease was first identified in the Wuhan city, Hubei Province, China. Coronavirus is the major health concern and devastating, especially for the children and elderly people. It is mainly caused by the Severe Acute Respiratory Syndrome (SARS$\mathrm{CoV}-2)$ hence it is also known as SARS- CoV-2 disease. Many studies have undergone but also there is a less data about the mortality of the clinical disease and less about it pathobiology [1,2]. Majorly cellular response of the virus is still unknown. Many studies and events based on the SARSCoV-2 are still going on from the past till present. India Stands the third position, all over the world, with a total of 3,461,240 Confirmed cases, 2,647,538 -Recovered, and

\section{Talluri Rameshwari K R}

Division of Microbiology, Department of Water \& Health, Faculty of Life Sciences, JSS Academy of Higher Education \& Research, Mysuru570015, Karnataka, India

Anuradha K

Department of Microbiology, Mysore Medical College and Research Institute, K R Hospital, Irwin Road, Mysore-570001 Karnataka, India Ajay Kumar Singh

Department of Environmental Microbiology, Babasaheb Bhimrao Ambedkar University (A Central University),

Lucknow, Uttar Pradesh - 226025)
62,713- Death cases respectively [3]. Where the USA stands in the first position in increased COVID-19 cases with 6,096,235 confirmed cases, 3,375,838 recovered, and 185,901 death cases. Turkmenistan and Western Sahara are at the least position, with zero cases $[4,5]$. In India, Maharashtra stands first with 82,968 confirmed cases, 37390 recovered and 2969 death cases separately. China was the first countries to be infected with this SARS- CoV-2 with 80,672 confirmed 76014 recovered and 4602 death cases respectively. Highest cases were found in Hubei Province with 68135 confirmed, 63623 recovered and 4512 death cases similarly least cases were observed in Liaoning Province 159, 150, \& 2 confirmed, recovered and death cases respectively. The COVID- 19 virus is mainly transmitted through droplets generated when an infected person coughs, sneezes, or exhales.

These droplets are too heavy to hang in the air, and quickly fall on floors or surfaces. You can be infected by breathing in the virus if you are within close proximity of someone who has COVID-19, or by touching a contaminated surface and then your eyes, nose or mouth. The virus can cause a range of symptoms, from ranging from mild illness to pneumonia. Symptoms of the disease are fever, cough, sore throat and headaches. So, the special care is indeed to avoid the spreading of this virus form the person to person. Then only, there is chance of decreasing the COVID-19 cases in India.

\section{TRANSMISSION}

\section{A. Pathogenesis of SARS-CoV-2-Virus}

Stage 1-Asymptomatic state: This is the initial days of the infection for about 1-2days. The inhaled virus SARS-CoV-2 binds to the epithelial cells in the nasal cavity and its starts its replication. The study of invitro explained the SARS-CoV-2 indicated the ciliated cells are primarily cells infected in the airways [5]. The innate immunity response is low in the local propagation. The virus is mainly a single stranded/cell RNA viruses which is a very smallest that 0.001 micrometer in its diameter and culturing of the virus is more difficult than compared to bacteria. As it is a minute the airways cells and no obvious cell type is preferred [6]. From the nasal swab detection the infection level may be slow but it's also increases the replication and leads to high body temperature. RT-PCR value for the viral single stranded RNA is the major thing used for the detection of this virus quickly and easily [7]. Super spreader of the virus can be detected by the RT-PCR method. The standardization of the RT-PCR protocol will be useful for the sample collection and processing procedure and also nasal swabs might be more sensitive than throat swabs [8]. 
Stage 2-Upper airways and conducting airways response: when the virus enters through the nasal cavity after the few days, the virus propagates and migrates down to the respiratory tract along with airways. Here more innate immune response is triggered. Hence it starts it replications. The markers of innate immune response and the nasal swabs and sputum should be yield for the SARS-CoV-2 sampling. The level of infection will leads to the death of the patients. The subsequent clinical courses can be predicted by the level of CXCL10 (or some other innate response cytokine). Where CXCL10 is a interferon responsive gene, gives the signaling to the alveolar type II cell response for both Influenza and SRAS-CoV-2 [8,9]. The host immune response detection may improve the predications on the subsequent course of the diseases. The diseases will be mild and restricted to upper respiratory tract and airways for more than $80 \%$ of the infected patients $[5,6]$.

Stage 3- Hypoxia, ground glass infiltrates and progression to Acute Respiratory Distress Syndrome (ARDS): Majority 20\% of the patients infected by all the three infection steps that develops the pulmonary infiltrates and some of theses develops very severe diseases. The fatality rate is about $2 \%$ for the diseases depending upon the age groups. The virus reaches the gas exchange units of the lung and infects alveolar type II cells. Type II cells are majorly infected by the SARS-CoV-2 and influenza than compared with type I cells [10]. They are commonly called as precursor cells of type I cells, which are majorly shown in influenza pneumonia [11]. A SARS and COVID-19 pathological result diffuses alveolar damage with fibrin rich hyaline membranes with few multinucleated giant cells. The disease may mainly occur in the elderly age group and younger age group due to their diminished immune response and reduce ability to repair the damaged epithelium, mucociliary clearance had reduced in the elderly age groups, which mainly lead to the virus spread and gas exchange units of the lung more readily $[12,13]$.

\section{B. Hand Washing Problems and their Importance}

In 1983 from the Journal of Health and Infection has published the data on the hands hygiene, as a review article with the most common transferring vehicles in the hospitals [17]. By the Kathryn French and his recent highlights gave the importance of the hygiene [18]. Summarized history from the study of Vermeil et. al., explained the hygiene process and hand rub which are depended study of the Pasteur, Lister, and other's [19]. WHO ass focused the theme "Clean care is in your Hands" in the 200th anniversary of Florence Nightingale's birth programme. Ohio hospitals studies form the Mortimer et. al., clearly showed the ethics of the hand washing but still some of the works stood unethical and they remained optimum in the practice of the hygiene. Best example was that methods of hand drying, paper towels, hot air dryers or jet air dryers (JAD) etc., [20]. The JAD's are ubiquitous, in the public aspects and hospitals point of view. Some of the studies also have done on this J nAD's comparison one of them are Best et. al., they found the higher rates of the environmental contamination in the JAD with some complications in the hospitals. Some of the studies required for the scoping of this JAD's [21]. Spanish intensive care unit has investigated the hospitals drainage problem which leads in causing the gram negative bacterial infection [22]. Hand washing problems created a more number of activities which sinks in a series. Majorly $4 \%$ of hand washing problem are leading to new diseases. The glove usage also caused the unnecessary usage so in order to overcome with this problem, the personal protective equipment (PPE) established in hospitals for increasing security purpose [23]. Glove hand disinfection also becomes the complaint of plastic usage. Where it should be used as appropriate, careful removal and disposal of gloves is more important as the environmental point of health hazard. When compared with the National and International hygiene process the hand washing is not a big compliant. Hawthorne effect of awareness for the hands hygiene was observed with the behaviorally study [24]. The work of the hygiene can be improved when once the compliance of the study is worked properly with importance of customizing messaging and interventions etc., some of the studies like Salmon et. al., of the context of different health care professionals [25]. The successful introducing of multimodal hand hygiene was framed by Brink et. al., [26]. Greenough et. al., presented a follow up of the previous years; published data of the hygienic process and their caring role, with nosocomial infection etc., Some of the good practice of hygiene is impacting on the common low and middle income countries which causes in the increase of the cases and also it's been considered on the impact of an educational intervention assessed in the countries [27].

\section{STATISTICAL ANALYSIS OF COVID-19 DATA (INDIA)}

\section{A. Descriptive Statistical Analysis}

It is mainly used for the basic features of the data. This gives the summary of the samples and the measures the total cases, with a simple graphics analysis they form the basis of virtually quantitative data. It is typically distinguished from inferential statistics [28]. Here the descriptive statistics simply shows what is and what the data explains, here the total confirmed, recovered \& death cases of COVID-19 cases in India are explained according to the prevalence (Table 1). We use inferential statistics to try to infer from the sample data what the population might think and also with use of inferential statistics helps in judgments of the probability that an observed difference between the two or three groups. In that one will be dependable and other two will be nondependable. Thus, we use inferential statistics to make inferences from our data to more general conditions; we use descriptive statistics simply to describe what's going on in our data. 


\section{B. One-Way ANOVA Analysis}

One-Way ANOVA it is commonly called as "analysis of variance" and also parametric test. It compares the two or more than two independent variance in groups in order to determine the statistical evidence is associated with the present data. In the study the confirmed data is statistical determined with recovered and death cases of the COVID-19 give the variance and perfect analysis (Table 2). The grouping of the variables as only two groups, its independent sample test $t$ test will be equivalent, it is calculated with the formula $\mathrm{t} 2=\mathrm{F}$. Here we compared with three groups hence it showed the regression variance. The confirmed cases were coefficiently compared with death cases in order to identify, how many deaths have occurred in total cases. Significantly the recovered cases were excluded in the data where they have been totally recovered.

TABLE I

THE DESCRIPTIVE STATISTICAL ANALYSIS OF THE CONFIRMED, RECOVERED AND DEATH CASES OF THE COVID- 19 IN INDIA DESCRIPTIVE STATISTICS

\begin{tabular}{cccccc}
\hline \hline & N & Minimum & Maximum & Mean & Std. Deviation \\
\hline Confirmed & 2 & 80672 & 240684 & 160678.00 & 113145.570 \\
Recovered & 2 & 76014 & 119728 & 97871.00 & 30910.466 \\
Deaths & 2 & 4602 & 6959 & 5780.50 & 1666.651 \\
Valid N (listwise) & 2 & & & \\
\hline
\end{tabular}

Confirmed

\begin{tabular}{llllll}
\hline \hline & & Frequency & Percent & Valid Percent & Cumulative Percent \\
\hline Valid & 80672 & 1 & 50.0 & 50.0 & 50.0 \\
& 240684 & 1 & 50.0 & 50.0 & 100.0 \\
& Total & 2 & 100.0 & 100.0 & \\
\hline
\end{tabular}

Recovered

\begin{tabular}{llllll}
\hline \hline & & Frequency & Percent & Valid Percent & Cumulative Percent \\
\hline Valid & 76014 & 1 & 50.0 & 50.0 & 50.0 \\
& 119728 & 1 & 50.0 & 50.0 & 100.0 \\
& Total & 2 & 100.0 & 100.0 & \\
\hline
\end{tabular}

Deaths

\begin{tabular}{llllll}
\hline \hline & & Frequency & Percent & Valid Percent & Cumulative Percent \\
\hline Valid & 4602 & 1 & 50.0 & 50.0 & 50.0 \\
& 6959 & 1 & 50.0 & 50.0 & 100.0 \\
& 2 & 100.0 & 100.0 & \\
\hline
\end{tabular}

TABLE II

SHOWS THE ONE-WAY ANOVA ANALYSIS OF THE COVID-19 CASES IN INDIA

ANOVA

\begin{tabular}{|c|c|c|c|c|c|c|}
\hline Model & & Sum of Squares & $\overline{\mathrm{df}}$ & Mean Square & $\bar{F}$ & Sig. \\
\hline \multirow[t]{5}{*}{1} & Regression & 12801920072.0 & 1 & 12801920072.0 & - & $\mathrm{b}$ \\
\hline & & 00 & & 00 & & - \\
\hline & Residual & .000 & 0 & - & & \\
\hline & Total & 12801920072.0 & & & & \\
\hline & & 00 & 1 & & & \\
\hline
\end{tabular}

a. Dependent variable: Confirmed 
Coefficients $^{\mathbf{a}}$

\begin{tabular}{|c|c|c|c|c|c|c|}
\hline \multirow[b]{2}{*}{ Model } & & \multicolumn{2}{|c|}{ Unstandardized Coefficients } & \multicolumn{2}{|c|}{$\begin{array}{l}\text { Standardized } \\
\text { Coefficients }\end{array}$} & \multirow[b]{2}{*}{ Sig. } \\
\hline & & $\mathrm{B}$ & Std. Error & Beta & $\mathrm{t}$ & \\
\hline \multirow[t]{2}{*}{1} & (Constant) & -231748.545 & .000 & & - & - \\
\hline & Deaths & 67.888 & .000 & 1.000 & - & - \\
\hline
\end{tabular}

a. Dependent Variable: Confirmed

Excluded Variables ${ }^{\mathrm{a}}$

\begin{tabular}{|c|c|c|c|c|c|c|}
\hline & & & & & & $\begin{array}{l}\text { Collinearity } \\
\text { Statistics }\end{array}$ \\
\hline \multirow[t]{2}{*}{ Model } & & Beta ln & $\mathrm{t}$ & Sig. & $\begin{array}{l}\text { Partial } \\
\text { Correlation }\end{array}$ & Tolerance \\
\hline & & $\mathrm{b}$ & & & & \\
\hline 1 & Recovered & - & - & - & - & .000 \\
\hline
\end{tabular}

\section{One-Way ANOVA Analysis}

Test statistic for one-way ANOVA is denotes as $F$ it is form an independent variables, $F$ evaluates the groups means significantly different. Because the computation of the $\mathrm{F}$ statistic is slightly more involved than computing the paired or independent samples $t$ test statistics (Table 3). F static is formulated with

$$
\mathrm{F}=\mathrm{MSR} / \mathrm{MSE}
$$

Where $\mathrm{MSR}=\mathrm{SSR} / \mathrm{df} \mathrm{r}=$ the regression mean square

$\mathrm{MSE}=\mathrm{SSE} / \mathrm{df}_{\mathrm{e}}=$ the mean square error

\section{Correlation}

A correlation coefficient is a numerical measure of the data the type of correlation means, statistical relationship between two or more variables, these variables are two column data for the set of observation, they are called as sample or component data with a known distribution (Table 4). Here, in the study the COVID-19 Confirmed cases are correlated with recovered and death cases. Approximately death cases from the total confirmed cases are correlated.

TABLE III

SHOWS THE $F$ STATISTICS VALUES OF THE COVID-19 ALL THREE CASES

One-Sample Statistics

\begin{tabular}{ccccc}
\hline \hline & $\mathrm{N}$ & Mean & Std. Deviation & Std. Error Mean \\
\hline Confirmed & 2 & 160678.00 & 113145.570 & 80006.000 \\
Recovered & 2 & 97871.00 & 30910.466 & 21857.000 \\
Deaths & 2 & 5780.50 & 1666.651 & 1178.500 \\
\hline
\end{tabular}

One-Sample Test

\begin{tabular}{ccccccc}
\hline \hline & & & Test value $=0$ \\
\hline & & & & & \multicolumn{2}{l}{$\begin{array}{l}\text { 95\% Confidence Interval of the } \\
\text { Difference }\end{array}$} \\
\hline & $\mathrm{t}$ & $\mathrm{df}$ & Sig. (2-tailed) & Mean Difference & Lower & Upper \\
Confirmed & 2.008 & 1 & .294 & 160678.000 & -855894.62 & 1177250.62 \\
Recovered & 4.478 & 1 & .140 & 97871.000 & -179848.52 & 375590.52 \\
Deaths & 4.905 & 1 & .128 & 5780.500 & -9193.76 & 20754.76 \\
\hline
\end{tabular}




\section{DRUG SUSCEPTIBILITY TEST PATTERN}

(COVID-19) spreads, attempts are made to minimize transmission through normal public health interventions focused on case-isolation and touch monitoring [29]. Joel Helle well and colleagues predict in their modeling analysis that such a strategy may contribute to the overall size of an outbreak, but will still be inadequate to achieve outbreak control of COVID-19 when the basic reproduction number (R0) is higher than 1.5 or the proportion of contacts monitored is lower than $80 \%$.One of Helle well and colleagues' key assumptions of the model is that all persons with symptomatic infection with serious acute respiratory syndrome (SARS) coronavirus (SARS-CoV-2) eventually should be tested and identified. Though, clinicians can only check infected patients under the criteria of most low-grade transmission countries if they have traveled to an epidemic area since the outbreak started [30]. A second assumption of this approach is that in stopping transmission, case isolation is 100 per cent effective. But home confinement of infected individuals and interactions is difficult, effectiveness is uncertain, and a significant amount of public health resources are needed for the extensive monitoring involved. The current emergency COVID-19 requires the urgent creation of new strategies to protect people at high risk of infection - especially close contacts and health- care staff, amongothers - even if more comprehensive antiviral therapy results are yet to come. High estimates of secondary attack levels of SARSCoV-2 in households ( 15 percent) and near contacts ( 10 percent) are a key explanation for such an approach. Pre-exposure prophylaxis and post-exposure prophylaxis (PEP) with antimicrobial drugs are effective in preventing disease before possible exposure or after reported exposure to a range of microbial pathogens, and in reducing disease risk [31, 32]. Based on experiences with PEP for other infections, after a recent possible exposure to SARS-CoV-2 we recommend starting PEP as soon as possible. For example, people exposed to index cases of invasive meningococcal infection are given PEP with rifampicin and WHO has prescribed oseltamivir for people at high risk of infection before or after exposure to pandemic influenza [33].

Antiviral drugs administered shortly after the onset of symptoms may reduce infectiousness to others by reducing viral shedding in patients' respiratory secretions (SARS-CoV2 viral load in sputum peaks at about 5-6 days after the onset of symptoms and lasts up to 14 days), and targeted prophylactic contact treatment can reduce their risk of infection [34]. There are several requirements regarding the implementation of antiviral treatment and prophylaxis. There are several requirements regarding the implementation of

TABLE IV

CORRELATION OF THE COVID-19 DATA ANALYSIS BY SPSS STATISTICAL METHOD

Correlations

\begin{tabular}{|c|c|c|c|c|c|}
\hline & & & Confirmed & Recovered & Deaths \\
\hline \multirow[t]{9}{*}{ Kendall's tau_b } & Confirmed & $\begin{array}{l}\text { Correlation } \\
\text { Coefficient }\end{array}$ & 1.000 & 1.000 & 1.000 \\
\hline & & Sig. (2-tailed) & - & - & - \\
\hline & & $\mathrm{N}$ & 2 & 2 & 2 \\
\hline & Recovered & $\begin{array}{l}\text { Correlation } \\
\text { Coefficient }\end{array}$ & $1.000^{* *}$ & 1.000 & 1.000 \\
\hline & & Sig. (2-tailed) & - & - & - \\
\hline & & $\mathrm{N}$ & 2 & 2 & 2 \\
\hline & Deaths & $\begin{array}{l}\text { Correlation } \\
\text { Coefficient }\end{array}$ & $1.000^{* *}$ & $1.000^{* *}$ & 1.000 \\
\hline & & Sig. (2-tailed) & - & - & - \\
\hline & & $\mathrm{N}$ & 2 & 2 & 2 \\
\hline \multirow[t]{9}{*}{ Spearman's rho } & Confirmed & $\begin{array}{l}\text { Correlation } \\
\text { Coefficient }\end{array}$ & 1.000 & 1.000 & 1.000 \\
\hline & & Sig. (2-tailed) & - & - & - \\
\hline & & $\mathrm{N}$ & 2 & 2 & 2 \\
\hline & Recovered & $\begin{array}{l}\text { Correlation } \\
\text { Coefficient }\end{array}$ & $1.000^{* *}$ & 1.000 & 1.000 \\
\hline & & Sig. (2-tailed) & - & - & - \\
\hline & & $\mathrm{N}$ & 2 & 2 & 2 \\
\hline & Deaths & $\begin{array}{l}\text { Correlation } \\
\text { Coefficient }\end{array}$ & $1.000^{* * *}$ & $1.000^{* *}$ & 1.000 \\
\hline & & Sig. (2-tailed) & - & - & - \\
\hline & & $\mathrm{N}$ & 2 & 2 & 2 \\
\hline
\end{tabular}


antiviral treatment and prophylaxis [35]. Hydroxychloroquine, the antimalarial medication, is approved for chemoprophylaxis and malaria treatment and as a disease-modifying antirheumatic product. This has a history of being healthy at normal doses, and well tolerated. Notably, the drug demonstrates in vitro antiviral activity against coronaviruses, and specifically, SARS-CoV-2.4 Based on observed drug concentrations and in vitro drug testing, pharmacological modeling indicates that prophylaxis with hydroxychloroquine at permitted doses could prevent SARS-CoV-2 infection and ameliorate viral discharge [36, 37]. Clinical trials are ongoing in China (NCT04261517 and NCT04307693) for hydroxychloroquine treatment for COVID-19 pneumonia [38]. The first study (NCT04261517) showed promising clinical preliminary findings (although not definitive due to the low sample size) management, with data expected to be published soon. Some are preparing a multicenter randomized controlled trial (NCT04304053) to assess the efficacy of antiviral treatment in someone who is found to be contaminated, and the efficacy of prophylactic hydroxychloroquine in preventing secondary SARS- CoV-2 infections and symptoms of disease in all contacts [39]. Our goal is to evaluate the reduction in SARS- CoV-2 transmissibility and the progression of disease among the contacts of an index case [40]. The design intervention is based on the template used during the 2015 Ebola çaSuffit vaccination trial. A newly diagnosed person with the disease becomes the index case, around who is built an epidemiologically defined ring of contact. This ring is then randomized on an open-label basis to either interference or control within a 1:1 ratio. The research will be performed during COVID-19 outbreak in Spain's Catalonia region, with initial results anticipated in May 2020. Identifying a COVID19 preventative drug will completely alter the course of the outbreak $[35,40]$.

\section{CONCLUSION}

The present study helps in identifying the COVID-19 pathogenesis, transmission, and its nature of activity, The COVID -19 is increasing because of its unknown features and the complexity of the population affected, there is an urgent care should be taken for the standard clinical trial designs on treatments, now a day's some may be in optimal for the immune weaker patients. The statistical study helps in identifying the disease spread and intensity and its future increasing status, so the care should be taken in this particular aspect. The World Health Organization (WHO) has taken measures to prevent the spreading of the COVID-19 in recent days and all the Central Government Institutes, Universities and Research Laboratories are working to get out from these diseases. The WHO regional and country offices are trying their best. In these aspects, our study helps in identifying the intensity, and spread of the COVID-19 disease very easily. The Statistical software that is used in the public health sectors for the first time to get the intensity of the disease infected in a particular region. By the help of the method we can further go for the analysis of the COVID-19 study in order to over the situation.

\section{REFERENCES}

[1] Fehling P, Hasenkamp J, Unkel S, Thalmann I, Hornig S, Tru"mper L, et al. Effect of gloved hand disinfection on hand hygiene before infection-prone procedures on a stem cell ward. J Hosp Infect 2019;103:321e7. https://doi.org/10.1016/ j.jhin.2019.06.004.

[2] Poller B, Hall S, Bailey C, Gregory S, Clark R, Roberts P, et al. "VIOLET": a fluorescence-based simulation exercise for training healthcare workers in the use of personal protective equipment.J Hosp Infect 2018;99:229e35. https://doi.org/10.1016/ j.jhin.2018.01.021.

[3] Hall S, Poller B, Bailey C, Gregory S, Clark R, Roberts P, et al. Use of ultraviolet-fluorescence-based simulation in evaluation of personal protective equipment worn for first assessment and care of a patient with suspected highconsequence infectious disease. J Hosp Infect 2018;99:218e28. https://doi.org/10.1016/j.jhin.2018.01.002.

[4] Munoz-Gutierrez KM, Canales RA, Reynolds KA, Verhougstraete MP. Floor and environmental contamination during glove disposal. J Hosp Infect 2019;101:347e53. https://doi.org/10.1016/j.jhin.2018.10.015.

[5] Wu Z, McGoogan JM. Characteristics of and important lessons from the coronavirus disease 2019 (COVID-19) outbreak in China: summary of a report of 72314 cases from the Chinese Center for Disease Control and Prevention. JAMA 2020; in press.

[6] Wan Y, Shang J, Graham R, et al. Receptor recognition by novel coronavirus from Wuhan: An analysis based on decadelong structural studies of SARS. J Virol 2020; 94: e00127-20.

[7] Hoffmann M, Kleine-Weber H, Schroeder S, et al. SARSCoV-2 cell entry depends on ACE2 and TMPRSS2 and is blocked by a clinically proven protease inhibitor. Cell 2020; in press.

[8] Sims AC, Baric RS, Yount B, et al. Severe acute respiratory syndrome coronavirus infection of human ciliated airway epithelia: role of ciliated cells in viral spread in the conducting airways of the lungs. J Virol 2005; 79: 15511-15524.

[9] Reyfman PA, Walter JM, Joshi N, et al. Single-cell transcriptomic analysis of human lung provides insights into the pathobiology of pulmonary fibrosis. Am J Respir Crit Care Med 2019; 199: 1517-1536.

[10] Tang NL, Chan PK, Wong CK, et al. Early enhanced expression of interferon-inducible protein-10 (CXCL-10) and other chemokines predicts adverse outcome in severe acute respiratory syndrome. Clin Chem 2005; 51: 2333-2340.

[11] Hancock AS, Stairiker CJ, Boesteanu AC, et al. Transcriptome analysis of infected and bystander type 2 alveolar epithelial cells during influenza A virus infection reveals in vivo Wnt pathway downregulation. J Virol 2018; 92:e01325-18.

[12] Qian Z, Travanty EA, Oko L, et al. Innate immune response of human alveolar type II cells infected with severe acute respiratory syndrome-coronavirus. Am J Respir Cell Mol Biol 2013; 48: 742-748. Wang J, Nikrad MP, Phang T, et al. Innate immune response to influenza A virus in differentiated human alveolar type II cells. Am J Respir Cell Mol Biol 2011; 45: 582-591.

[13] Rockx B, Baas T, Zornetzer GA, et al. Early upregulation of acute respiratory distress syndrome- associated cytokines promotes lethal disease in an aged-mouse model of severe acute respiratory syndrome coronavirus infection. J Virol 2009; 83: 7062-7074.

[14] Mossel EC, Wang J, Jeffers S, et al. SARS-CoV replicates in primary human alveolar type II cell cultures but not in type Ilike cells. Virology 2008; 372: 127-135. 
[15] Weinheimer VK, Becher A, Tonnies M, et al. Influenza A viruses target type II pneumocytes in the human lung. J Infect Dis 2012; 206: 1685-1694.

[16] Reybrouck G. Role of the hands in the spread of nosocomia infections. J Hosp Infect 1983;4:103e10. https://doi.org/ 10.1016/0195-6701(83)90040-3.

[17] French K. Ten articles on hand hygiene innovation that have been reported in the Journal of Hospital Infection. J Hosp Infect 2018;100:242e3. https://doi.org/10.1016/j.jhin.2018.07.045.

[18] Vermeil T, Peters A, Kilpatrick C, Pires D, Allegranzi B, Pittet D. Hand hygiene in hospitals: anatomy of a revolution. J Hosp Infect 2019;101:383e92. https://doi.org/10.1016/j.jhin.2018.09.003.

[19] Mortimer EA, Wolinsky E, Gonzaga AJ, Rammelkamp CH. Role of airborne transmission in staphylococcal infections. BMJ 1966;1:319e22. https://doi.org/10.1136/bmj.1.5483.319.

[20] Mutters R, Warnes SL. The method used to dry washed hands affects the number and type of transient and residential bacteria remaining on the skin. J Hosp Infect 2019;101:408e13. https://doi.org/10.1016/j.jhin.2018.12.005.

[21] Best E, Parnell P, Couturier J, Barbut F, Le Bozec A, Arnoldo L, et al. Environmental contamination by bacteria in hospital washrooms according to hand-drying method: a multi-centre study. J Hosp Infect 2018;100:469e75. https://doi.org/10.1016/j.jhin.2018.07.002.

[22] Weinbren M. Down the drain and back up a drain. J Hosp Infect 2019;102:61e2. https://doi.org/10.1016/j.jhin.2019.01.027.

[23] Aranega-Bou P, George RP, Verlander NQ, Paton S, Bennett A, Moore G, et al. Carbapenem-resistant Enterobacteriaceae dispersal from sinks is linked to drain position and drainage rates in a laboratory model system. J Hosp Infect 2019;102:63e9. https:// doi.org/10.1016/j.jhin.2018.12.007.

[24] Feng Y, Wei L, Zhu S, Qiao F, Zhang X, Kang Y, et al. Handwashing sinks as the source of transmission of ST16 carbapenem-resistant Klebsiella pneumoniae, an international high-risk clone, in an

[25] intensive care unit. J Hosp Infect 2019. https://doi.org/10.1016/ j.jhin.2019.10.006.

[26] Turner C, Mosby D, Partridge D, Mason C, Parsons H. A patient sink tap facilitating carbapenemase- producing enterobacteriales transmission. J Hosp Infect 2019. https://doi.org/10.1016/j.jhin.2019.12.020 (in Press).Shaw E, Gavalda` L, Ca`mara J, Gasull R, Gallego S, Tubau F, et al. Control of endemic multidrug- resistant Gram-negative bacteria after removal of sinks and implementing a new watersafe policy in an intensive care unit. J Hosp Infect 2018;98:275e81. https://doi.org/10.1016/j.jhin.2017.10.025.

[27] Tracy M, Ryan L, Samarasekara H, Leroi M, Polkinghorne A, Branley J. Removal of sinks and bathing changes to control multidrug-resistant Gram-negative bacteria in a neonatal intensive care unit: a retrospective investigation. J Hosp Infect 2020. https://doi.org/10.1016/j.jhin.2020.01.014 (in Press).

[28] Grabowski M, Lobo JM, Gunnell B, Enfield K, Carpenter R, Barnes L, et al. Characterizations of handwashing sink activities in a single hospital medical intensive care unit. $\mathrm{J}$ Hosp Infect 2018;100:e115e22. https://doi.org/10.1016/j.jhin.2018.04.025.

[29] Mahida N. Hand hygiene compliance: are we kidding ourselves? J Hosp Infect 2016;92:307e8. https://doi.org/10.1016/ j.jhin.2016.02.004.

[30] Dalziel C, McIntyre J, Chand AG, McWilliam S, Ritchie L. Validation of a national hand hygiene proxy measure in NHS
Scotland. J Hosp Infect 2018;98:375e7. https://doi.org/10.1016/ j.jhin.2017.10.001.

[31] Borg MA, Brincat A. Addressing the controversy of $100 \%$ hand hygiene compliance: can alcohol rub consumption data serve as a useful proxy validator? J Hosp Infect 2018;100:218e9. https://doi.org/10.1016/j.jhin.2018.04.024.

[32] Hellewell J, Abbott S, Gimma A, et al. Feasibility of controlling COVID-19 outbreaks by isolation of cases and contacts. Lancet Glob Health 2020; published online Feb 28.

[33] Qifang Bi, Yongsheng Wu, Shujiang Mei, et al. Epidemiology and transmission of COVID-19 in Shenzhen China: analysis of 391 cases and 1286 of their close contacts. medRxiv 2020; published online March 4.

[34] Welliver R, Monto AS, Carewicz O, et al. Effectiveness of oseltamivir in preventing influenza in household contacts: a randomized controlled trial. JAMA 2001; 285: 748-54.

[35] Yao X, Ye F, Zhang M, et al. In vitro antiviralactivity and projection of optimized dosing design of hydroxychloroquine for the treatment of severe acute respiratory syndrome coronavirus 2 (SARS-CoV-2). Clin Infect Dis 2020; published online March 9.

[36] Tett SE, Cutler DJ, Day RO, Brown KF. Bioavailability of hydroxychloroquine tablets in healthy volunteers. Br J Clin Pharmacol 1989; 27: 771-79

[37] Henao-Restrepo AM, Camacho A, Longini IM, et al. Efficacy and effectiveness of an rVSV-vectored vaccine in preventing Ebola virus disease: final results from the Guinea ring vaccination, open-label, cluster-randomised trial (Ebola Ça Suffit!). Lancet 2017; 389: 505-18.

[38] Tett SE, Cutler DJ, Day RO, Brown KF. Bioavailability of hydroxychloroquine tablets in healthy volunteers. Br J Clin Pharmacol 1989; 27: 771-79

[39] Henao-Restrepo AM, Camacho A, Longini IM, et al. Efficacy and effectiveness of an rVSV-vectored vaccine in preventing Ebola virus disease: final results from the Guinea ring vaccination, open-label, clusterrandomised trial (Ebola Ça Suffit!). Lancet 2017; 389: 505-18.

[40] Paules CI, Marston HD, Fauci AS. Coronavirus infections - more than just the common cold. JAMA. Published online January 23, 2020. doi:10.1001/jama. 2020.0757 


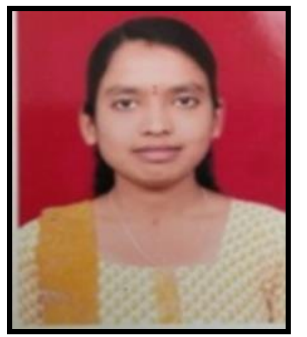

Ms. Talluri Rameshwari $\mathbf{K} \quad \mathbf{R}$ completed Bachelor of Science degree from Dept. of Microbiology, University of Mysore, Mysuru, Karnataka, India. She has been completed Masters in Science in Microbiology, University of Mysore, Mysuru, Karnataka India. Currently, working as Research Scholar, Division of Microbiology, Department of Water \& Health, Faculty of Life Sciences, JSS Academy of Higher Education \& Research, Mysuru-570015, Karnataka, India. She has been published several National and International Research Articles in the field of Microbiology. She filed two patents and attended More than 35 National and International Conference, Participated and presented a several Oral and Poster Presentation, and also attended 25 Training Programmers', along with 10 Workshops.

Dr. Anuradha K. completed MBBS and MD in Microbiology. Currently working as a Professor \& HOD, Department of Microbiology, Mysore Medical College \& Research Institute, Irwin Road, Mysore - 570001 and a Nodal officer for the integrated disease surveillance project (IDSP), Member of board of studies of Vishweshvaraya Technical University (VTU),Belgaum for water and technology course, Member of board of studies under graduate (M.B;B.S)course of Rajiv Gandhi University Of Health Sciences(RGUHS), Member of Doctoral committee for $\mathrm{PhD}$ studies JSS University etc., Attended many National and international conferences. Published more than 20 papers in peer review journals.

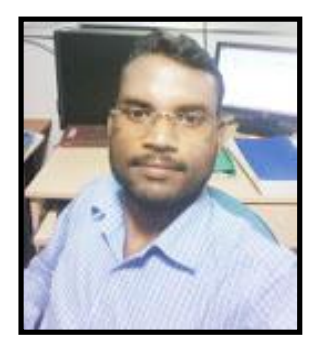

Mr. Ajay Kumar Singh completed M.Sc. in Industrial Microbiology and pursuing Ph.D. in Environmental Microbiology from Department of Environmental Microbiology, Babasaheb Bhimrao Ambedkar University, Lucknow, Uttar Pradesh, India. He has been published one Indian Patent, more than five research papers in Peer Reviewed Journals and book chapters at National and International levels. $\mathrm{He}$ is the members of different Scientific Societies, and Reviewers in several journals. 